\title{
TESTPERFORMANCE OF MINIATUR BOILER FOR DRYING KERUPUK WITH VARIOUS PRESSURE AND VARIOUS DIRECTION OF AIR CIRCUITS
}

\author{
Ahmad Maulana K' ${ }^{1}$, Aa Setiawan², Wardika $^{3}$ \\ Jurusan Teknik Pendingin dan Tata Udara, Politeknik Negeri Indramayu 1,2,3 \\ Jl. Raya Lohbener lama No.08 - Indramayu, Jawa Barat \\ e-mail: ahmedmaulana21@yahoo.co.id', aasetiawan123@yahoo.com², \\ wardika123@yahoo.com³
}

\begin{abstract}
In the industrial center of kerupuk in Indramayu, drying kerupuk by using boiler is done if the weather conditions are cloudy or rainy. The kerupuk drying process uses the boiler by utilizing a steam pressure of 4 bar and passing it to the heat exchanger ( $h x$ ) for heating air in the drying chamber. To achieve 4 bar pressure on the boiler takes a long time, about 3-4 hours duration so it is less effective in its use. If the steam working pressure on the boiler is reduced to 3 or 2 bar, it will likely save the drying time of the kerupuk. For that we need to test the process of drying kerupuk with pressure variations 2, 3 and 4 bars in order to know the difference in performance. In addition to variations of vapor pressure, the test is also carried out with variations in the direction of air flow to the position of the dried kerupuk, ie the position of vertikal direction and horizontal direction position but with the same pressure that is 4 bar. The test was carried out on a miniatur kerupuk dryer boiler with a design tailored to the conditions in the field. From the test results obtained the value of loss of drying (LOD) kerupuk at 4 bar pressure has a value of $46.4 \%$ and $43.8 \%$, while at pressure 3 and 2 bar LOD values $38.4 \%$ and $31.1 \%$. It can be said that the working pressure of 4 bar is indeed an effective pressure to be used in the process of drying the kerupuk. For the combustion efficiency of the boiler also, the pressure of 4 bar is higher when compared to the efficiency at 3 and 2 bar pressure. As for the direction of air flow, the direction of the vertikal position of the kerupuk more effectively used in the process of drying kerupuk compared the horizontal direction.
\end{abstract}

Keywords: boiler, heat exchanger, loss of drying, efficiency.

\section{UJI PERFORMANSI MINIATUR BOILER PENGERING KERUPUK DENGAN VARIASI TEKANAN KERJA DAN ARAH ALIRAN UDARANYA}

\begin{abstract}
ABSTRAK
Pada sentra industry kerupuk yang ada di Indramayu, pengeringan kerupuk dengan menggunakan boiler dilakukan jika kondisi cuaca sedang mendung atau hujan. Proses pengeringan kerupuk menggunakan boiler tersebut dengan memanfaatkan tekanan uap sebesar 4 bar dan mengalirkannya ke bagian heat exchanger $(h x)$ untuk memanaskan udara pada ruang pengering. Untuk mencapai tekanan 4 bar pada boiler tersebut membutuhkan waktu yang lama, sekitar $3-4$ jam lamanya sehingga kurang efektif dalam penggunaannya. Jika tekanan kerja uap pada boiler tersebut dikurangi menjadi 3 atau 2 bar, kemungkinan akan menghemat waktu pengeringan kerupuk tersebut. Untuk itu perlu dilakukan pengujian proses pengeringan kerupuk dengan variasi tekanan 2,3 dan 4 bar agar dapat diketahui perbedaan performansinya. Selain variasi tekanan uap, pengujian juga dilakukan dengan variasi arah aliran udaranya terhadap posisi kerupuk yang dikeringkan, yaitu posisi arah vertikal dan posisi arah horizontal
\end{abstract}


namun dengan tekanan sama yaitu 4 bar. Pengujian dilakukan pada miniatur boiler pengering kerupuk dengan desain yang disesuaikan dengan kondisi di lapangan. Dari hasil pengujian didapat nilai loss of drying (LOD) kerupuk pada tekanan 4 bar memiliki nilai $46.4 \%$ dan $43.8 \%$, sedangkan pada tekanan 3 dan 2 bar memliki nilai LOD 38.4\% dan 31.1\%. Dapat dikatakan bahwa tekanan kerja 4 bar memang tekanan yang efektif untuk digunakan pada proses pengeringan kerupuk tersebut. Untuk efisiensi pembakaran pada boiler juga, tekanan 4 bar yang lebih tinggi nilainya bila dibandingkan dengan efisiensi pada tekanan 3 dan 2 bar. Sedangkan untuk arah aliran udara, arah vertikal terhadap posisi kerupuk memang lebih efektif digunakan pada proses pengeringan kerupuk dibandingkan arah horizontal.

Kata kunci: boiler, heat exchanger, loss of drying, efisiensi.

\section{PENDAHULUAN}

Industri kerupuk di Indramayu merupakan jenis usaha mikro (ukm) yang berkembang secara turun temurun dari beberapa generasi sejak tahun 1980an. Salah satu pusat mikro industri kerupukyang ada di Indramayu terdapat di Desa Kenanga Blok Dukuh. Terdapat lebih dari 10 unit ukm kerupuk yang ada di daerah tersebut. Dalam memproduksi kerupuk tersebut, para pengusaha biasanya memanfaatkan sinar matahari untuk mengeringkan adonan kerupuk yang sudah jadi hingga menjadi kering dan siap untuk di jual. Namun jika kondisi cuaca sedang mendung, maka proses pengeringan adonan kerupuk tersebut menggunakan boiler biomassa berbahan bakar kayu bakar. Boiler yang digunakan untuk pengering kerupuk tersebut merupakan jenis boiler horizontal berbentuk tabung dengan panjang $5 \mathrm{~m}$ dan diameter sekitar $1 \mathrm{~m}$.

Proses pengeringan kerupuk menggunakan boiler tersebut memanfaatkan uap panas bertekanan yang dihasilkan dari boiler dan mengalirkannya ke bagian penukar kalor (heat exchanger, $H x$ ) untuk memanaskan udara. Udara panas keluar $H x$ inilah yang nantinya disalurkan ke bagian ruang pemanas dimana kerupuk ditempatkan untuk dikeringkan. Tekanan kerja uap panas yang dihasilkan pada boiler tersebut disetel pada posisi $4-5$ bar (gauge). Waktu yang di butuhkan untuk mencapai tekanan kerja yang sebesar 5 bar tersebut cukup lama yaitu sekitar 4 jam lamanya. Setelah tekanan kerja boiler tersebut mencapai tekanan yang di inginkan (5 bar), maka kerupuk mulai di tempatkan di oven pengeringnya di bagian atas (sisi bagian exhaust). Jika tekanan kerja pada boiler tersebut di set pada tekanan rendah (misal 2 - 3 bar), maka kemungkinan akan mempercepat proses pengeringan sehingga mengurangi konsumsi bahan bakar yang digunakan dan sekaligus mengurangi biaya produksinya.

Selain itu, penempatan kerupuk yang akan di keringkan di ruang pengering juga ada pada bagian atas ovennya. Hal ini tentu saja kurang efektif karena tidak searah dengan aliran udara panas yang dihembuskan ke ruang pengering (oven) tersebut (lihat gambar 1. berikut).

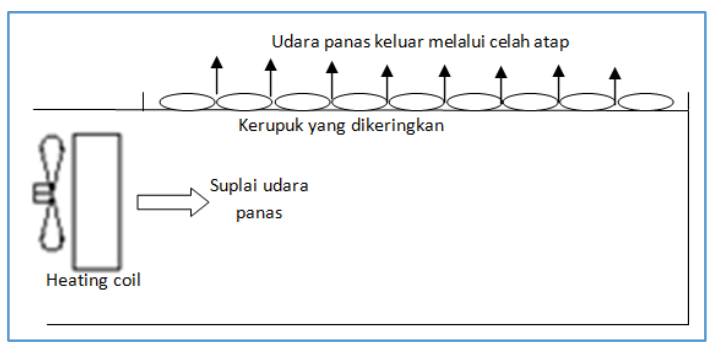

Gambar 1. skema ruang pengering (oven) kerupuk dengan posisi kerupuk yang tidak searah dengan aliran udaranya

Jika posisi kerupuk yang akan di keringkan di tempatkan pada bagian dalam oven yang searah dengan aliran udara panasnya (dengan tambahan rak) maka kemungkinan akan dapat mengoptimalkan proses pengeringan kerupuk sehingga dapat mengurangi banyaknya bahan bakar boiler yang digunakan. Berdasarkan pada masalah tersebut diatas, maka penelitian ini dilakukan dengan tema kegiatan adalah "uji performansi miniatur boiler pengering kerupuk dengan variasi tekanan kerja dan arah udaranya". Pengujian performansi boiler 
tersebut dilakukan dengan cara membuat miniatur yang sesuai dengan desain boiler yang ada di lapangan namun dengan ukuran yang relatif kecil agar dapat lebih mudah dalam pengambilan data dan analisanya.

\section{METODE PENELITIAN}

Tahapan awal yang akan dilakukan dalam pelaksanaan penelitian ini adalah terlebih dahulu membuat desain (rancangan) dari miniatur boiler yang akan dibuat. Rancangan tersebut disesuaikan skemanya semirip mungkin dengan boiler yang ada di lapangan, namun dengan ukuran yang jauh lebih kecil. Rencananya, bagian boiler dan bagian ruang oven (pengering) yang akan digunakan tersebut berbahan dasar tangki besi dengan diameter $25 \mathrm{~cm}$ dan panjang 50 $\mathrm{cm}$. Dan gambar rancangannya hampir mirip dengan skema boiler pengering kerupuk yang ada pada gambar 1.1 diatas hanya saja untuk penempatan kerupuknya di letakkan di bagian dalam oven dengan tambahan rak.

Untuk memudahkan dalam pengambilan data, maka sumber pembakaran air pada boiler tersebut berasal dari pembakaran gas LPG dengan kompor gas yang terpasang pada bagian bawah tangki air boilernya. Setelah skema rancangan miniatur boiler selesai dibuat, maka selanjutnya adalah menentukan alat dan bahan yang diperlukan dalam pelaksanaan penelitian ini. Jika desain boiler dan bahan sudah siap, maka langkah selanjutnya adalah membuat miniatur boiler tersebut sesuai dengan desain yang telah ditentukan. Berikut ini adalah skema dari rancangan boiler yang telah dibuat.

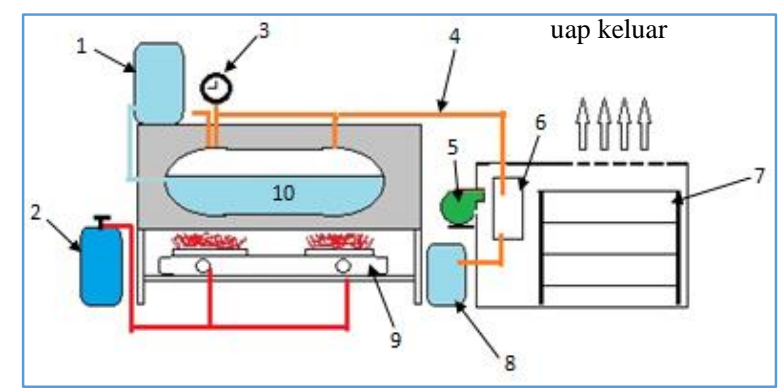

Gambar 2. Skema rancangan boiler dan ruang pengering kerupuk dengan rak
Keterangan Gambar 2:

1. Tangki pengisi air

2. Tabung LPG

3. Pressure gauge

4. Saluran uap panas

5. Blower

6. Heat exchanger $(H x)$

7. Rak wadah kerupuk

8. Penampung uap

9. Kompor gas

10. Tangki uap boiler

Proses pembuatan miniatur boiler pengering kerupuk tersebut dimulai dari pembuatan tangki air yang terbuat dai tabung bekas dengan diameter sekitar $25 \mathrm{~cm}$ yang kemudian di modifikasi tambahan berupa saluran isi air dan saluran uap panas. Setelah itu baru membuat ruang pengering untuk kerupuknya. Selanjutnya adalah melakukan pengujian pengeringan kerupuk untuk mendapatkan data - data yang diperlukan dalam analisa kinerja boiler pengering kerupuk yang telah dibuat tersebut.

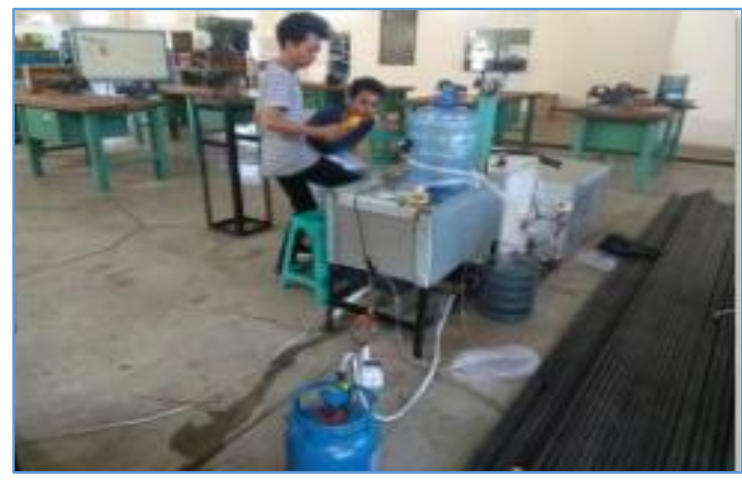

Gambar 3. Pengujian miniatur boiler pengering kerupuk

Pengujian boiler pengering kerupuk tersebut dilakukan dengan variable tetap berupa : massa kerupuk basah yang dikeringkan sebanyak $2 \mathrm{~kg}$, waktu pengeringan kerupuk selama 2 jam, dan menggunakan bahan bakar yang sama yaitu berasal dari gas LPG dengan sistem 2 kompor. Pengujian juga dilakukan sebanyak 4 kali dengan variasi tekanan kerja boiler dan variasi arah aliran udara terhadap penempatan kerupuknya. Keempat jenis pengujian dengan variasi tekanan dan arah aliran udara tersebut dijelaskan seperti 
kondisi di bawah ini:

1. Pengujian ke-1: pengujian dengan tekanan kerja 3-4 bar dengan arah aliran udara vertikal (disebut uji 4V).

2. Pengujian ke-2: pengujian dengan tekanan kerja 3-4 bar dengan arah aliran udara horizontal (disebut uji 4H).

3. Pengujian ke-3: pengujian dengan tekanan kerja 2-3 bar dengan arah aliran udara horizontal (disebut uji $3 \mathrm{H}$ ).

4. Pengujian ke-4: pengujian dengan tekanan kerja 1-2 bar dengan arah aliran udara vertikal (disebut uji $2 \mathrm{H}$ ).

Pengambilan data diperlukan sebagai dasar untuk menentukan performansi (kinerja) dari boiler yang digunakan sebagai pengering kerupuk tersebut dan membandingkan hasilnya.Pengambilan data dilakukan dengan cara mengukur tiga jenis temperatur pada sisi saluran uap, yaitu temperatur air, titik uap masuk dan keluar $H x$. Sedangkan pada sisi udara, dilakukan pengukuran temperatur untuk mengetahui kondisi udara panasnya. Titik pengukuran pada sisi udara tersebut adalah pada bagian udara masuk dan keluar blower, pada ruang pemanas, dan pada sisi uap keluar ruang pemanas.

Sebuah timbangan digital juga digunakan untuk mengetahui jumlah massa bahan bakar gas LPG yang disuplai pada proses pembakaran sehingga dapat diketahui laju konsumsi bahan bakarnya (FCR). Timbangan digital juga digunakan untuk mengetahui massa awal dan massa akhir produk kerupuk yang dikeringkan. Dengan mengetahui massa awal dan akhir kerupuk tersebut, maka dapat akan dapat diketahui berapa jumlah uap air pada kerupuk yang telah menguap / dikeringkan sehingga susut pengeringan (loss of drying, LOD) kerupuk untuk tiap pengujian dapat diketahui.

\section{TINJAUAN PUSTAKA}

Untuk mempermudah dalam mengevaluasi kinerja boiler, maka dalam perhitungan efisiensi boiler menggunakan metode langsung. Metode langsung ini dikenal juga sebagai 'metode input-output' karena metode ini hanya memerlukan keluaran/output (steam) dan panas masuk/input (bahan bakar) untuk evaluasi efisiensi. Efisiensi boiler dengan metode langsung ini dapat dievaluasi dengan menggunakan persamaan berikut [1]:

$$
\begin{gathered}
\text { Eff boiler }(\eta)=\frac{\text { Energi output }}{\text { energi input }} \times 100 \% \\
=\frac{\dot{m}_{\text {steam }} \times\left(h_{g}-h_{f}\right)}{\dot{m}_{\text {fuel }} \times G C V} \times 100 \%
\end{gathered}
$$

Dimana

hg - Entalpi steam jenuh dalam $\mathrm{kJ} / \mathrm{kg}$ steam

hf - Entalpi air umpan dalam $\mathrm{kJ} / \mathrm{kg}$ air

$\dot{m}_{\text {steam }}-$ Jumlah steam yang dihasilkan per jam dalam kg/jam

$\dot{m}_{\text {fuel }^{-}}$Jumlah bahan bakar yang digunakan per jam dalam $\mathrm{kg} / \mathrm{jam}$

GCV - nilai panas kotor bahan bakar dalam $\mathrm{kJ} / \mathrm{kg}$ bahan bakar. Nilai GCV untuk LPG adalah $46607 \mathrm{~kJ} / \mathrm{kg}$ [2]

Selain kinerja boiler yang diperhitungkan, kondisi udara kering pada proses pemanasan udara pada heat exchanger $(H x)$ juga perlu dianalisa. Semakin tinggi udara panas yang dihasilkan pada sisi output $H x$ maka akan semakin rendah kelembaban udaranya dan akan berakibat pada makin cepat pula terjadinya pengeringan kerupuk pada ruang pengering tersebut. Untuk mengetahui laju pengeringan kerupuk pada proses tersebut dapat dilakukan dengan cara menghitung susut pengeringan selama proses berlangsung. Istilah susut pengeringan umumnya disebut dengan LOD (loss on drying), yaitu suatu pernyataan kelembaban / kadar air pada suatu produk terhadap berat basah atau berat awal produk itu sendiri. Jika dirumuskan dengan rumus baku, maka laju pengeringan produk (kerupuk) tersebut dapat dihitung dengan menggunakan rumus berikut [3].

$$
\begin{aligned}
\text { LOD } & =\frac{\text { massa kadar air }}{\text { massa produk basah (awal) }} \times 100 \% \\
& =\frac{m_{\text {moisture }}}{m_{o}} \times 100 \%
\end{aligned}
$$




$$
=\frac{\left(m_{o-} m_{a}\right)}{m_{o}} \times 100 \%
$$

Dimana

LOD - tingkat pengeringan produk, $\%$

$m_{\text {moisture }}-$ massa kadar air yang hilang, $\mathrm{kg}$

$m_{o}$ - massa basah produk (massa awal), $\mathrm{kg}$ $m_{a}-$ massa produk kering (massa akhir), $\mathrm{kg}$

\section{HASIL DAN PEMBAHASAN}

Berdasarkan pada pengujian yang telah dilakukan, diperoleh beberapa data temperatur pada boilerdengan variasi pengujian tekanan dan arah aliran udaranya. Tabel 1 berikut ini merupakan tabel data pengukuran temperatur uap dan udara pada sisi hx dan sisi ruang pengering. Uji $4 \mathrm{~V}$ merupakan pengujian dengan tekanan 4 bar arah udara vertikal, uji $4 \mathrm{H}$ merupakan pengujian dengan tekanan 4 bar arah udara horizontal, uji $3 \mathrm{H}$ merupakan uji dengan tekanan 3 bar arah udara horizontal dan uji 2H merupakan uji dengan tekanan 2 bar arah udara horizontal. Selain dalam bentuk tabel, fluktuasi kenaikan temperatur pada boiler juga disajikan dalam bentuk grafik. Grafik 1 merupakan grafik temperatur uap pada sisi hx untuk masing - masing pengujian, grafik 2 merupakan grafik temperatur udara pada sisi hx dan grafik 4.3 merupakan grafik temperatur udara ruang pengering.

Tabel 1. data temperatur proses pengeringan kerupuk dengan variasi tekanan dan arah aliran udaranya

\begin{tabular}{|c|c|c|c|c|c|c|c|c|c|c|c|c|}
\hline \multirow{2}{*}{$\begin{array}{c}\text { Menit } \\
\mathrm{Ke}\end{array}$} & \multicolumn{4}{|c|}{ Temp. uap hx, oC } & \multicolumn{4}{|c|}{ Temp. udara hx, oC } & \multicolumn{4}{|c|}{ Temp. ruang pengering, oC } \\
\hline & i $4 \mathrm{~V}$ & Uji 4H & Uji 3H & Uji $2 \mathrm{H}$ & Uji 4V & Uji 4H & $\mathrm{Uji} 3 \mathrm{H}$ & Uji 2 & Uji 4V & Uji 4H & $\mathrm{Uji} 3 \mathrm{H}$ & $\mathrm{Uji} 2$ \\
\hline 0 & 30.6 & 29.6 & 31.3 & 30.3 & 28.0 & 30.8 & 30.8 & 29.0 & 30.8 & 31.2 & 30.1 & 9.8 \\
\hline 10 & 12. & 70.3 & 8 & 51.8 & 34.6 & 32.9 & 32.9 & 30.6 & 35.3 & 33.3 & 3.8 & 32.1 \\
\hline 20 & 83. & 89. & 69.4 & 64.6 & 35.1 & 34.9 & 34.9 & 33.4 & 35.1 & 34.0 & 33.2 & .2 \\
\hline 30 & 94 & 98 & 74.8 & 74.6 & 35.4 & 37.9 & .9 & 33.9 & 36.2 & 34.1 & 32.9 & 8 \\
\hline 40 & 112.2 & 111 & 84.4 & 81.4 & 35.3 & 45.8 & 8 & 34.5 & 35.8 & 37.8 & 33.7 & 1.9 \\
\hline 50 & 138.4 & 126.0 & 93.4 & 87.2 & 57.4 & 54.6 & 4.6 & 4.6 & .0 & 9.4 & 6 & 3.2 \\
\hline 60 & 137.6 & 13 & 114.0 & 92.8 & 118.7 & 114.8 & 5.6 & 4.9 & & 58.5 & 2 & 33.7 \\
\hline 70 & 136 & 4 & 8 & 117.6 & .1 & 117.1 & 11 & 55.1 & & .8 & 6 & 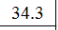 \\
\hline 80 & & 135.2 & 8 & 120.8 & 123.3 & 114.3 & 114.3 & 116.0 & & & & .7 \\
\hline 90 & 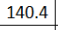 & 13 & 1 & 113.2 & & & .8 & & 59.6 & 56.6 & .2 & 1.3 \\
\hline 100 & 13 & 4 & 132.8 & 11 & 121.9 & 119.3 & 109.3 & $a_{1}$ & 9 & 60.8 & 50.8 & .4 \\
\hline 110 & 2 & 13 & 135.6 & 119.4 & 3 & 118.7 & 108.7 & 3.9 & 5 & 3 & .6 & 3.8 \\
\hline 120 & 134.6 & 135.8 & 134.2 & 125.8 & 122.9 & 119.1 & 109.1 & 114.2 & 63.2 & 64.5 & 57.6 & 53.2 \\
\hline
\end{tabular}

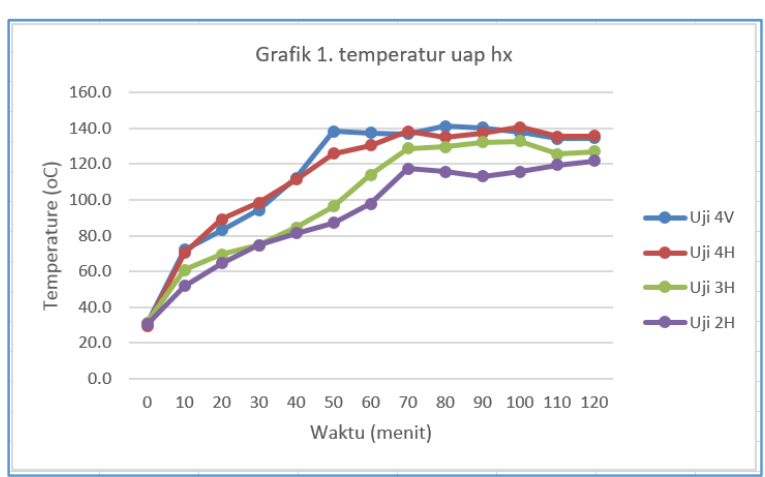

Gambar 4. Grafik Temperatur Uap $H x$

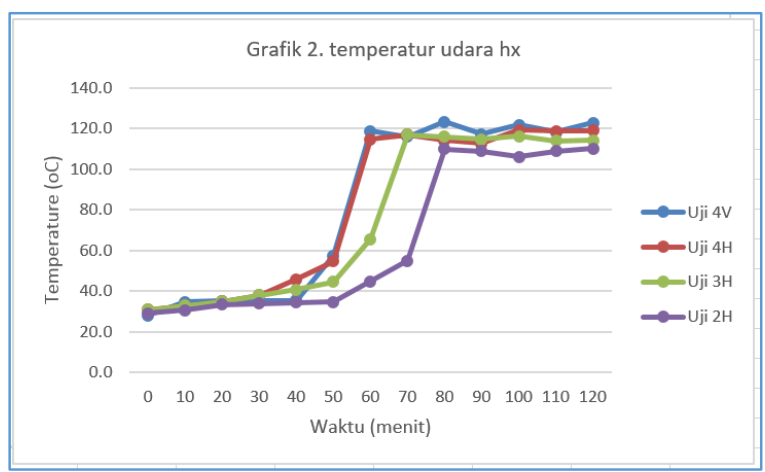

Gambar 5. Grafik Temperatur Udara $H x$

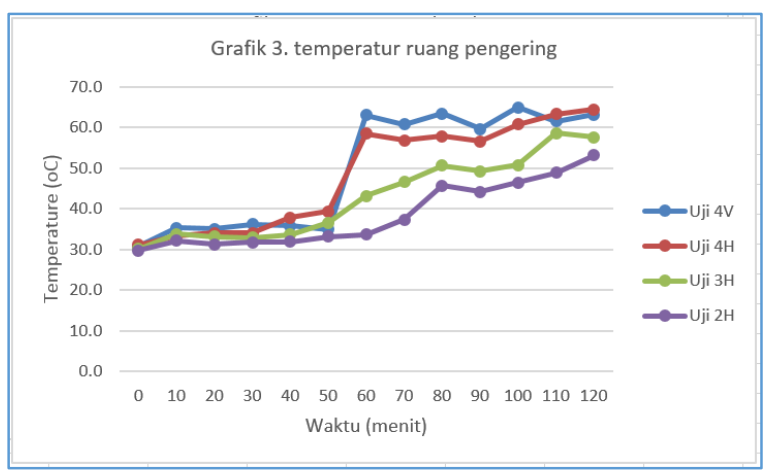

Gambar 6. Grafik Temperatur Ruang Pengering

Terlihat pada tabeldan ketiga grafik diatas, untuk jenis pengujian $4 \mathrm{~V}$ dan $4 \mathrm{H}$ memiliki fluktuasi temperatur yang hampir sama baik pada temperatur uap maupun pada temperatur ruang pengering. Pengujian $4 \mathrm{~V}$ dan $4 \mathrm{H}$ ini memiliki nilai yang lebih baik daripada pengujian $3 \mathrm{H}$ dan $2 \mathrm{H}$. Hal ini menunjukkan bahwa pengaturan tekanan 4 bar pada boiler akan menghasilkan temperatur optimal pada ruang pengering (temperatur ruang berkisar pada nilai 63.2 $64.5^{\circ} \mathrm{C}$ ). Sedangkan pada pengaturan tekanan 
3 bar dan 2 bar pada boiler akan berakibat kurang panasnya temperatur ruang pengering (temperatur ruang berkisar pada nilai 53.2 $57.6{ }^{\circ} \mathrm{C}$ ), hal ini disebabkan karena laju aliran uap yang relatif lebih sedikit sehingga proses perpindahan kalor pada $h x$ jadi lebih kecil.

Tabel 2 merupakan tabel hasil perhitungan (hasil olah data) untuk menganalisa dan membandingkan performansi proses pengeringan pada boiler untuk tiap variasi pengujian. Terlihat pada tabel 2 tersebut bahwa nilai LOD pada uji $4 \mathrm{~V}$ dan uji $4 \mathrm{H}$ memiliki nilai yang lebih tinggi daripada uji $3 \mathrm{H}$ dan uji $2 \mathrm{H}$ (uji $4 \mathrm{~V}$ dan $4 \mathrm{H}$ memiliki nilai LOD $46.4 \%$ dan $43.8 \%$, nilai LOD untuk uji $3 \mathrm{H}$ dan $2 \mathrm{H}$ adalah $38.4 \%$ dan $31.1 \%$ ). Dengan demikian, pengaturan tekanan 4 bar pada boiler lebih sesuai untuk digunakan daripada tekanan 3 bar atau 2 bar pada proses pengeringan kerupuk tersebut. Terlihat pada tabel 2 juga untuk pengujian dengan tekanan yang sama namun berbeda arah aliran udara (uji 4V dan uji 4H), kondisi arah aliran udara vertikal memiliki nilai LOD yang lebih besar daripada aliran udara horizontal (LOD uji 4V 46.4\% dan LOD uji 4H 43.8\%). Hal ini disebabkan karena pada arah aliran udara vertikal terhadap produk, akan mengakibatkan turbulensi aliran pada ruangan sehingga proses pengeringan jadi lebih merata dan susut pengeringan pun jadi lebih besar. Dengan demikian, posisi arah aliran udara vertikal memang lebih baik daripada posisi arah aliran udara horizontal terhadap produk.

Tabel 2. Hasil pengolahan data pengujian

\begin{tabular}{|c|l|c|c|c|c||}
\hline \multirow{2}{*}{ No } & \multicolumn{2}{|c|}{ Parameter } & \multicolumn{4}{|c|}{ Jenis pengujian } \\
\cline { 3 - 6 } & & Uji 4V & Uji 4H & Uji $3 \mathrm{H}$ & Uji $2 \mathrm{H}$ \\
\hline 1 & waktu pengujian, $(\mathrm{min})$ & 120 & 120 & 120 & 120 \\
\hline 2 & massa produk awal, mo (kg) & 2.09 & 2.08 & 2.03 & 2.06 \\
\hline 3 & massa produk akhir, ma (kg) & 1.12 & 1.17 & 1.25 & 1.42 \\
\hline 4 & massa kadar air, $(\mathrm{kg})$ & 0.97 & 0.91 & 0.78 & 0.64 \\
\hline $\mathbf{5}$ & Susut pengeringan, LOD (\%) & $\mathbf{4 6 . 4}$ & $\mathbf{4 3 . 8}$ & $\mathbf{3 8 . 4}$ & $\mathbf{3 1 . 1}$ \\
\hline 6 & massa LPG awal, mo lpg (kg) & 13.85 & 13.06 & 12.43 & 11.81 \\
\hline 7 & massa LPG akhir, ma lpg (kg) & 13.21 & 12.43 & 11.81 & 11.19 \\
\hline 8 & laju massa LPG, (kg/jam) & 0.320 & 0.315 & 0.310 & 0.310 \\
\hline 9 & Nilai GCV LPG, $(\mathrm{kJ} / \mathrm{kg})$ & 46607 & 46607 & 46607 & 46607 \\
\hline 10 & Temp. air umpan, oC & 28.0 & 30.8 & 30.8 & 29.0 \\
\hline 11 & Entalphi air umpan, hf (kJ/kg) & 125 & 125 & 125 & 125 \\
\hline 12 & Temp. uap tertinggi, oC & 140.4 & 140.8 & 132.2 & 121.8 \\
\hline 13 & Tekanan kerja uap, bar & 4 & 4 & 3 & 2 \\
\hline 14 & Entalphi uap jenuh, hg (kJ/kg) & 2739 & 2739 & 2725 & 2712 \\
\hline 15 & massa air awal, mo air $(\mathrm{kg})$ & 7.74 & 7.92 & 7.68 & 7.87 \\
\hline 16 & massa air akhir, ma air $(\mathrm{kg})$ & 5.25 & 5.49 & 5.89 & 6.28 \\
\hline 17 & laju massa uap, $(\mathrm{kg} /$ jam) & 1.245 & 1.215 & 0.895 & 0.795 \\
\hline $\mathbf{1 8}$ & Effisiensi boiler, (\%) & $\mathbf{2 1 . 8}$ & $\mathbf{2 1 . 6}$ & $\mathbf{1 6 . 1}$ & $\mathbf{1 4 . 2}$ \\
\hline
\end{tabular}

Untuk efisiensi boiler, nilai pada pengujian tekanan 4 bar memiliki nilai yang lebih tinggi yaitu berkisar $21.6-21.8 \%$ daripada nilai efisiensi pada pengujian dengan tekanan 3 bar atau 2 bar yang sebesar $14.2-16.1 \%$. Hal ini disebabkan karena laju massa uap yang lebih banyak mengalir jika tekanan uap lebih tinggi, sehingga makin banyak energi yang dihasilkan pada boiler yang berakibat pada nilai efisiensi yang lebih besar. Dengan demikian dapat disimpulkan bahwa semakin tinggi tekanan kerja boiler maka akan semakin efektif proses pengeringan kerupuknya.

\section{KESIMPULAN}

Berdasarkan pada percobaan yang telah dilakukan tersebut, dapat diambil beberapa kesimpulan seperti berikut ini, yaitu:

1. Tekanan kerja boiler yang efektif untuk proses pengeringan kerupuk adalah pada tekanan 4 bar karena memiliki temperatur ruang pengering yang lebih tinggi dan memiliki nilai LOD (loss of drying) yang lebih besar bila dibandingkan dengan tekanan kerja 3 bar dan 2 bar (nilai LOD pada tekanan 4 bar adalah $46.4 \%$ dan $43.8 \%$, nilai LOD untuk tekanan 3 bar dan 2 bar adalah $38.4 \%$ dan $31.1 \%$ ).

2. Kondisi pengeringan dengan arah aliran udara vertikal terhadap posisi kerupuk yang dikeringkan, lebih efektif daripada dengan arah aliran udara horizontal mengingat dengan arah aliran udara vertikal dapat terjadi turbulensi aliran udara pada ruang pengering. Akibat dari turbulensi aliran udara tersebut adalah terjadinya pemerataan panas pada ruang pengering sehingga proses pengeringan kerupuk menjadi lebih cepat. Hal ini ditunjukkan dengan nilai LOD pada arah aliran vertikal yang lebih besar bila dibandingkan dengan arah aliran udara horizontal (nilai LOD vertikal adalah $46.4 \%$ dan nilai LOD horizontal adalah $43.8 \%)$. 
3. Semakin tinggi tekanan kerja uap pada boiler juga dapat meningkatkan efisiensi pada boiler tersebut mengingat dengan tekanan tinggi tersebut akan menyebabkan semakin besar uap yang dihasilkan sehingga energi output boiler pun makin banyak yang terpakai sehingga efisiensinya makin besar.

\section{DAFTAR PUSTAKA}

[1]. Pedoman Efisiensi Energi untuk Industri di Asia. (2006) United Nations Environment Programme (UNEP)www.energiefficiencyasia.org.

[2]. Keating, Eugene L. 2007. Applied Combustion,Second Edition. Taylor \& Francis Group, LLC. New York USA.

[3]. Rankell AS, Lieberman HA, Schiffman RF. 1986. Drying, The Theory and Practice of Industrial Pharmacy. Philadelphia, Lea \& Febiger. 